University of Nebraska - Lincoln

DigitalCommons@University of Nebraska - Lincoln

Agronomy \& Horticulture -- Faculty Publications

Agronomy and Horticulture Department

$1-25-2021$

\title{
Soil properties limiting vegetation establishment along roadsides
}

Shad D. Mills

Martha Mamo

Sabrina J. Ruis

Humberto Blanco-Canqui

Walter Schacht

See next page for additional authors

Follow this and additional works at: https://digitalcommons.unl.edu/agronomyfacpub

Part of the Agricultural Science Commons, Agriculture Commons, Agronomy and Crop Sciences Commons, Botany Commons, Horticulture Commons, Other Plant Sciences Commons, and the Plant Biology Commons

This Article is brought to you for free and open access by the Agronomy and Horticulture Department at DigitalCommons@University of Nebraska - Lincoln. It has been accepted for inclusion in Agronomy \& Horticulture -Faculty Publications by an authorized administrator of DigitalCommons@University of Nebraska - Lincoln. 


\section{Authors}

Shad D. Mills, Martha Mamo, Sabrina J. Ruis, Humberto Blanco-Canqui, Walter Schacht, Tala Awada, Xu Li, and Pamela Sutton 


\title{
Soil properties limiting vegetation establishment along roadsides
}

\author{
Shad D. Mills, ${ }^{1}$ Martha Mamo, ${ }^{1}$ Sabrina J. Ruis, ${ }^{1}$ \\ Humberto Blanco-Canqui, ${ }^{1}$ Walter H. Schacht, ${ }^{1}$ \\ Tala Awada, ${ }^{2}$ Xu Li, ${ }^{3} \&$ Pamela Sutton ${ }^{1}$
}

\begin{abstract}
1 Agronomy and Horticulture, University of Nebraska-Lincoln, Lincoln, NE 68583, USA 2 School of Natural Resources, University of Nebraska-Lincoln, Lincoln, NE 68583, USA

3 Department of Civil and Environmental Engineering, University of Nebraska-Lincoln, Lincoln, NE 68588, USA

Correspondence - Sabrina J. Ruis, Agronomy and Horticulture, University of Nebraska-Lincoln, Lincoln, NE 68583,USA. Email: sruis2@unl.edu
\end{abstract}

$\begin{array}{ll}\text { Martha Mamo } & \underline{\text { https://orcid.org/0000-0003-0307-6070 }} \\ \text { Sabrina J. Ruis } & \underline{\text { https://orcid.org/0000-0002-8769-9453 }} \\ \text { Humberto Blanco-Canqui } & \text { https://orcid.org/0000-0002-9286-8194 } \\ \text { Xu Li } & \underline{\text { https://orcid.org/0000-0002-1006-3027 }}\end{array}$

\begin{abstract}
Roadside vegetation provides a multitude of ecosystem services, including pollutant remediation, runoff reduction, wildlife habitat, and aesthetic scenery. Establishment of permanent vegetation along paved roads after construction can be challenging, particularly within $1 \mathrm{~m}$ of the pavement. Adverse soil conditions could be one of the leading factors limiting roadside vegetation growth. In this study, we assessed soil physical and chemical properties along a transect perpendicular to the road at six microtopographic positions (road edge, shoulder, side slope, ditch, backslope, and field edge) along two highway segments near Beaver Crossing and
\end{abstract}

To cite this article: Mills SD, Mamo M, Ruis SJ, et al. Soil properties limiting vegetation establishment along roadsides. J. Environ. Qual. 50:1 (2021), pp 110-121. doi:10.1002/jeq2.20184

Copyright (c) 2020 Shad D. Mills, Martha Mamo, Sabrina J. Ruis, Humberto Blanco-Canqui, Walter H. Schacht, Tala Awada, Xu Li, \& Pamela Sutton. Published by Wiley. Used by permission.

Submitted 20 March 2020; accepted 1 December 2020; published 25 January 2021. 
Sargent, NE. At the Beaver Crossing site, Na concentration was 81 times, exchangeable Na 66 times, and cone index (compaction parameter) six times higher at the road-edge position (closest to the paved road and with sparse vegetation) compared to positions with abundant vegetation (ditch or field edge). At the Sargent site, Na concentration was 111 times, exchangeable Na 213 times, and cone index up to two times higher at the road-edge position compared with ditch or field-edge positions. Likewise, electrical conductivity was higher and macroaggregation and water infiltration were lower at the road edge than at the ditch or field-edge positions. Soil properties improved with increasing distance from the road. Exchangeable Na percentage and cone index at the road-edge position exceeded threshold levels for the growth of sensitive plants. Thus, high $\mathrm{Na}$ concentration and increased compaction at the road edge appear to be the leading soil properties limiting vegetation establishment along Nebraska highways.

Abbreviations: EC, electrical conductivity; CEC, cation exchange capacity; NDOT, Nebraska Department of Transportation.

\section{Core Ideas}

- Roadside soil properties varied with microtopographic position along a transect perpendicular to paved road.

- The road edge had highest compaction, $\mathrm{Na}$, electrical conductivity, and $\mathrm{pH}$.

- The road edge had the lowest water infiltration and macroaggregation.

- Roadside compaction, $\mathrm{Na}$, and electrical conductivity exceeded threshold levels for plants.

\section{Introduction}

Establishing permanent vegetation along roadsides is essential to maintain or enhance ecosystem services. Well-established vegetation can provide many regulating, provisioning, cultural, and recreational ecosystem services. Specifically, it can stabilize slopes, control erosion, reduce water and air pollution, and improve natural aesthetic appeal, habitat for wildlife, and others (Akbar, Hale, \& Headley, 2003; Barrett, Lantin, \& Austrheim-Smith, 2004; Kasten, Stenolen, Caldwell, \& Oberhauser, 2016; McCleery, Holdorf, Hubbard, \& Peer, 2015; Ozdemir, 2019). For example, vegetative cover along roadsides can reduce total suspended solids by $77-97 \%$ and $\mathrm{Cu}, \mathrm{Pb}$, and $\mathrm{Zn}$ by 76 $98 \%$ at vegetation widths of 4.2-13 m (Barrett et al., 2004). Roadsides 
can also provide important refuge for insects, birds, and small mammals, particularly in areas dominated by agriculture (McCleery et al., 2015; Daniels et al., 2018; Kasten et al., 2016). In open landscapes like the U.S. Great Plains, snowdrifts can be a major problem. However, the standing residue from roadside vegetation traps snowfall, reducing labor to clear the snowdrifts. Roadsides with little or no surface cover are often eroded and have reduced ecosystem service potential.

Establishment of vegetation postconstruction is often difficult, especially within $1 \mathrm{~m}$ of the pavement. For example, in Nebraska, despite repeated seeding efforts by the Nebraska Department of Transportation (NDOT), vegetation does not establish well on some roadsides (NDOT, personal communication, 2014). Some of the factors limiting vegetation establishment could include adverse soil properties, hot and dry microclimates, vehicle traffic emissions, road maintenance activities, and the use of deicing salts (Forman et al., 2003; Neher, Asmussen, \& Lovell, 2013). Roadside soils are highly disturbed and generally compacted as a result of mixing, traffic, and addition of "fill" soil or gravel (Forman et al., 2003). As a result, soil properties along roadsides can be degraded and very different from those in the surrounding landscape.

Therefore, the research question is: How do the soil properties near the road edge compare with those further away from the road? The few previous studies located in New York, North Dakota, and Vermont reported increased bulk density and reduced water infiltration at the road-edge position compared with non-road edges, attributed to construction, traffic, and vibrations consolidating soils (Neher et al., 2013; Willmert, Osso, Twiss, \& Langen, 2018). Similarly, soil pH, electrical conductivity $(\mathrm{EC})$, and sodium $(\mathrm{Na})$ can be higher near road edges than on the non-road edges (Bryson\&Barker, 2002). The differences in soil chemical properties can be potentially due to mixing of soil horizons during construction and winter maintenance activities (Matthees, Hopkins, \& Casey, 2018; Neher et al., 2013; Willmert et al., 2018). The majority of the few existing studies were from the eastern United States, with relatively higher precipitation compared with Nebraska (Bryson \& Barker, 2002; Neher et al., 2013; Willmert et al., 2018). The study from North Dakota, although in a similar climate, was conducted after oil well access road removal and not along highways in the region (Matthees et al., 2018). Thus, the novelty of this work is 
the investigation of soil properties along road edges in a much drier climate than the eastern United States, where ice storms, blizzards, and large shifts in weather patterns are common. The road segments were situated in grassland and agricultural regions, whereas the previous studies from the eastern United States were conducted in forested regions.

There exists a need for additional research to investigate the factors such as soil properties potentially limiting vegetation establishment along roadsides for different states and road conditions. Specifically, studies comprehensively evaluating soil physical and chemical properties along highways in Nebraska and the Great Plains region are unavailable. Knowledge of differences in soil properties between road edges and non-road edges is needed to implement mitigation and soil restoration strategies (Haan, Hunter, \& Hunter, 2012). Thus, our study objectives were (a) to determine how soil physical and chemical properties change along a transect perpendicular to the road at six microtopographic positions (road edge, shoulder, side slope, ditch, backslope, and field edge) along two Nebraska highway segments and (b) to identify which soil physical and chemical properties exceeded the thresholds for plant growth. We hypothesized that soil properties would be above threshold levels for plant establishment and growth at the road-edge position compared with positions further from the road (Table 1).

Table 1. Ideal levels of some soil properties for plant agronomic growth (note that variability exists by soil type and plant species tolerance)

\begin{tabular}{lll} 
Soil property & Ideal level & Reference \\
\hline Bulk density & $<1.80 \mathrm{~g} \mathrm{~cm}^{-3}$ & Weil \& Brady, 2017 \\
Cone index & $<2 \mathrm{MPa}$ & Tormena et al., 1999 \\
Electrical conductivity & $<1.2 \mathrm{ds} \mathrm{m}^{-1}$ & Smith \& Doran, 1996 \\
Exchangeable Na percentage & $<15$ & Tisdale et al., 1993 \\
$\mathrm{pH}$ & $6.5-7$ for most agronomic crops & Tisdale et al., 1993 \\
Organic matter & $4-5 \%$ & Weil \& Brady, 2017 \\
Amount of macroaggregates & $\sim 66 \%$ & Ruis et al., 2017; Weil \& Brady, 2017 \\
\hline
\end{tabular}




\section{Materials and methods}

\subsection{Description of the study sites}

This study was conducted using two highway segments: L80E (40.79 $\mathrm{N},-97.29 \mathrm{~W}$ ) near Beaver Crossing in southeastern Nebraska and US$183(41.65 \mathrm{~N},-99.38 \mathrm{~W})$ near Sargent in central Nebraska. These two highway segments were selected because the NDOT identified them as areas where they had difficulty establishing perennial vegetation. At the Beaver Crossing site, mean maximum temperature was $15.9^{\circ} \mathrm{C}$ and mean annual precipitation was $743 \mathrm{~mm}$. The soils in the area were predominantly Hastings silt loam (fine, smectitic, mesic udic Argiustolls), Crete silt loam (fine, smectitic, mesic pachic udertic Argiustolls), and Fillmore silt loam (fine, smectitic, mesic vertic Argialbolls). These soil series are generally very deep, silty soils with a clayey subsoil and nearly level to gentle slopes ( $<1 \%$ slope). The highway was two-lane with no structural dividers and was level within the landscape. Traffic volume was 1,600 vehicles $d^{-1}$.

At the Sargent site, the mean maximum temperature was $16.4{ }^{\circ} \mathrm{C}$ and mean annual precipitation was $661 \mathrm{~mm}$. The soils in the area were predominantly Valentine fine sand (mixed, mesic typic Ustipsamments) with $<21 \%$ slope, Elsmere loamy fine sand (sandy, mixed, mesic aquic Haplustolls) with $<1 \%$ slope, and Tryon loamy fine sand (mixed, mesic typic Psammaquents) with $2 \%$ slope. These soils are generally deep sandy soils formed in alluvium or eolian sand, and the site was nearly level to moderately steep. The highway was two-lane with no structural dividers and was level within the landscape. Traffic volume was 1,385 vehicles $\mathrm{d}^{-1}$; about $15 \%$ of the vehicles were heavy trucks. For both sites, road construction activities likely mixed the natural horizons; thus, the soils along the roadside likely do not directly classify into these soil series.

\subsection{Experimental design}

Field measurements and soil sampling were conducted in spring 2014 at six locations at each site (Figure 1). At the Beaver Crossing site, the locations were spaced every $3.2 \mathrm{~km}$ along a $17.7-\mathrm{km}$ highway segment (Figure 1). At the Sargent site, the locations were every $1.6 \mathrm{~km}$ 
(a)

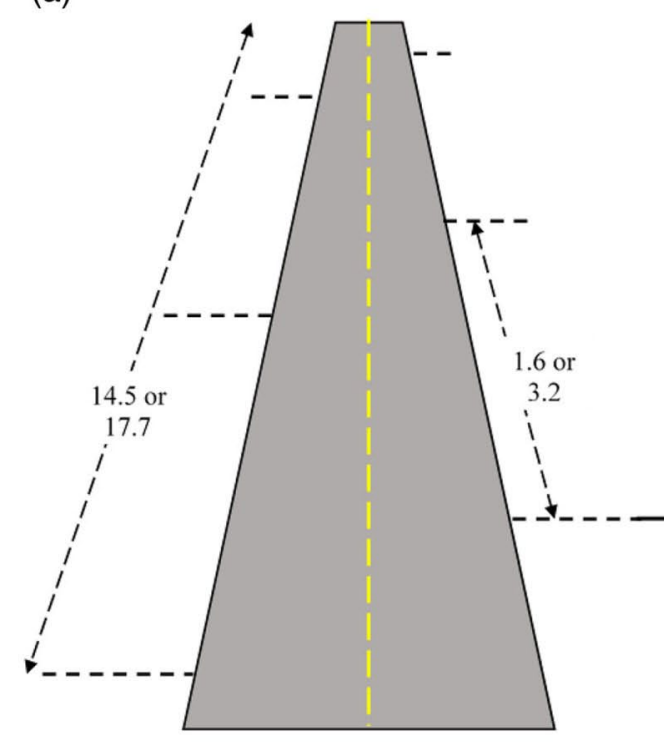

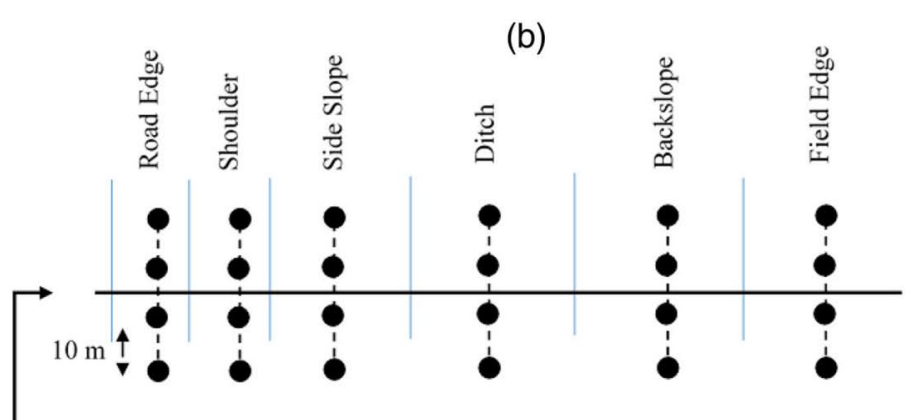

(c)

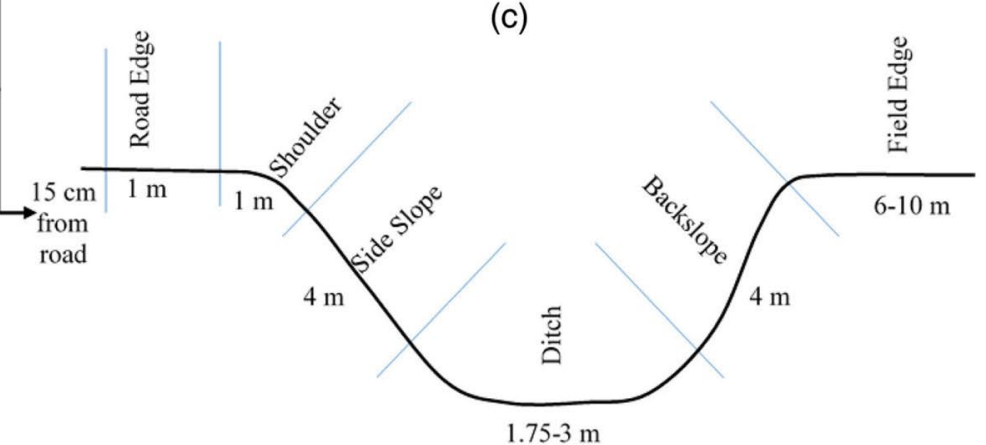

Figure 1. Sampling transects (dashed lines) where soil chemical and physical properties (a) were determined along highway segments near Beaver Crossing and Sargent, NE. At each sampling transect, six microtopographic positions (road edge, shoulder, side slope, ditch, backslope, and field edge (b) were sampled with each microtopographic position having four subsampling points along a $40 \mathrm{~m}$ transect (c). Diagram is not to scale. The number of samples collected was 144 per sampling depth per site, for a total of 576 samples for both sites

along a $14.5-\mathrm{km}$ highway segment (Figure 1). Each of the six locations was subdivided by microtopographic position along a transect perpendicular to the road. These microtopographic positions were road edge, shoulder, side slope, ditch, backslope, and field edge (Figure 1). Each microtopographic position was subsampled along a 40-m transect parallel to the road at 10-m intervals (Figure 1). The number of samples collected was 144 per sampling depth per site, for a total of 576 samples. The ditch, backslope, and field-edge positions had abundant amounts of vegetation compared with other microtopographic positions, particularly the road-edge position, which had very sparse vegetation. The field-edge position, which was at the field edge, was agricultural land at the Beaver Crossing site and grazing lands at the Sargent site. 


\subsection{Soil measurements}

Soil physical and chemical properties, including bulk density, cone index, sorptivity, wet aggregate stability, $\mathrm{pH}, \mathrm{EC}$, and concentrations of organic matter and other nutrients, were assessed at each site. These selected soil properties include indicators of compaction (bulk density and cone index), water infiltration (sorptivity), soil structure (wet aggregate stability), and nutrient status (chemical properties), which we predicted could be factors influencing vegetation establishment. We collected intact soil cores from the 0 -to-20-cm depth at each subsampling point within the six microtopographic positions. To collect the intact cores, we used a $4.7-\mathrm{cm}$-diameter hammer-driven soil sampler with stainless steel liners for the road-edge and shoulder positions and a $2.2-\mathrm{cm}$-diameter zero-contamination sleeve sampler at all other positions. The hammer-driven sampler was used for the roadedge and shoulder positions because these positions were compacted and difficult to sample with standard soil probes. During construction, gravel and fill addition and subsequent compaction for stabilization of the road bed are common. Soil cores were transported to the laboratory in a cooler, sliced at 0 -to-10-cm and 10-to-20-cm depths, and stored at $4{ }^{\circ} \mathrm{C}$ until analysis. At the time of soil core collection, we also collected bulk soil samples from each microtopographic position for the 0 -to-10-cm and $10-$ to- $20-\mathrm{cm}$ depths. The bulk samples were air-dried for $72 \mathrm{~h}$ and passed through sieves with 8-mm openings by gently crushing larger aggregates.

Penetration resistance, a compaction indicator, was measured for the 0 -to-10-cm and 10-to-20-cm depths using a hand penetrometer (Eijkelkamp, Giesbeek, The Netherlands) (Lowery \& Morrison, 2002) at each subsampling point within the six microtopographic positions. Cone index, in $\mathrm{MPa}$, was determined by dividing the penetrometer reading by the base area of the cone $\left(1 \mathrm{~cm}^{2}\right)$. Because cone index is correlated with changes in soil water content, the measured values were adjusted to a common water content (Blanco-Canqui, Lal, Owens, Post, \& Izaurralde, 2006; Busscher, Bauer, Camp, \& Sojka, 1997).

Sorptivity, or initial water infiltration, was measured as described by Smith (1999) at each subsampling point for the road-edge, shoulder, side-slope, ditch, and field-edge positions. Steel rings (diameter, 9.8 $\mathrm{cm}$ ) were driven into the soil to $2.5-\mathrm{cm}$ depth while avoiding cracking 
the soil surface. Prior to the ring insertion, any debris or plant material was removed without disturbing the soil surface. Water $(75 \mathrm{ml})$ was poured into the ring, and the amount of time required for the water to infiltrate was recorded to obtain sorptivity (Smith, 1999).

A fraction of the soil sample from the cores was air-dried and analyzed for bulk density, a compaction indicator, and chemical properties. Bulk density was assessed by the core method (Blake and Hartge, 1986), pH and EC using a 1:1 water ratio (Whitney, 2011a), and concentration of organic matter by the loss-on-ignition method (Nelson \& Sommers, 1996). The concentration of nitrate- $\mathrm{N}$ was assessed through $\mathrm{KCl}$ extraction and determination using the $\mathrm{Cd}$ reduction method (Gelderman \& Beegle, 2011). Concentrations of $\mathrm{K}, \mathrm{Ca}, \mathrm{Na}$, $\mathrm{Mg}, \mathrm{Zn}, \mathrm{Fe}, \mathrm{Mn}$, and $\mathrm{Cu}$ were determined through extraction with ammonium acetate or diethylenetriamine pentaacetate and assessment using atomic absorption spectrometry (Warncke \& Brown, 2011; Whitney, 2011b). Concentrations of $P$ and $S$ were assessed using Mehlich III extraction and colorimetric reading of the extract on a spectrophotometer (Frank, Beegle, \& Denning, 2011). The cation exchange capacity (CEC) was assessed using the methods described by Sumner and Miller (1996). The concentration of $\mathrm{Cl}$ was determined through the methods described by Adriano and Doner (1982), As through methods described by Ganje and Rains (1982), Cd and Ni by the methods of Baker et al. (1982), Cr by the methods of Reisenauer (1982), and Pb by the methods of Burau (1982).

Granulometric and particle size analysis (Gee \& Bauder, 1986) was conducted on the bulk soil samples for each microtopographic position and depth from one transect on each side of the road. A soil subsample of 100-300 g, depending on sample size, was sieved through $4.75 \mathrm{~mm}$. The contents of the $4.75-\mathrm{mm}$ sieve were termed "gravel." The remainder of the sample was passed through 4-, 2.38-, and 2-mm sieves; washed to remove additional aggregates; dried at $105^{\circ} \mathrm{C}$; weighed; and termed "gravel 4-4.75 mm," "pebbles 2.38-4 mm," and "pebbles 2-2.38 $\mathrm{mm}$." About $40 \mathrm{~g}$ of the 2-mm sieved sample were shaken for $16 \mathrm{~h}$ with $100 \mathrm{ml}$ of $5 \%$ sodium hexametaphosphate solution. The soil texture was determined from this solution using the hydrometer method to determine the percentage of sand, silt, and clay (Gee \& Bauder, 1986).

Using the bulk samples, soil wet-aggregate stability was determined by the wet-sieving method (Nimmo \& Perkins, 2002) to describe the 
soil structural quality. Air-dry soil samples were gently crushed to pass an 8-mm sieve. About $50 \mathrm{~g}$ of the 8-mm sieved soil was placed on top of sieves with $4.75-$ and $0.25-\mathrm{mm}$ openings, saturated by capillarity with distilled water for $10 \mathrm{~min}$, and then sieved in water using a mechanical wet sieving apparatus for another 10 min (Nimmo \& Perkins, 2002). Soil aggregates remaining on each sieve were transferred to beakers and dried at $105^{\circ} \mathrm{C}$ for $24 \mathrm{~h}$. Samples were weighed, treated with sodium hexametaphosphate for $24 \mathrm{~h}$, and washed through 0.053 $\mathrm{mm}$ sieves to correct for sand content (Nimmo \& Perkins, 2002). The sand-free fraction of soil aggregates was then used to compute the fraction of macroaggregates $(>0.25 \mathrm{~mm}$ ).

\subsection{Statistical analysis}

Data were assessed by site (Beaver Crossing or Sargent) and depth $(0-10 \mathrm{~cm}$ and $10-20 \mathrm{~cm})$ for normality using the Shapiro-Wilk test (SAS Institute, 2019). Data that were nonnormally distributed were log transformed if needed, and residuals were checked for normality. Data were analyzed using ANOVA with the PROC MIXED in SAS for a completely randomized design with highway microtopographic positions (road edge, shoulder, side slope, ditch, backslope, and field edge) as the "treatment" and each location as "replication." Correlations among select soil properties were investigated using PROC CORR by site for the 0 -to-10-cm depth. Differences were considered significant at the .05 probability level.

\section{Results}

\subsection{Soil chemical properties}

Soil chemical properties (including $\mathrm{pH}, \mathrm{EC}$, and concentrations of organic matter) and nutrients differed among microtopographic positions (road edge, shoulder, side slope, ditch, backslope, and field edge) at both sites (Table 2). At the Beaver Crossing site, soil pH at the 0 -to-10-cm depth changed with microtopographic position in the order: road edge (8.40) $>$ shoulder $=$ side slope $>$ ditch $=$ backslope $>$ field edge (5.90). At the Sargent site, soil pH for the same depth followed the order: road edge (8.20) $=$ shoulder $=$ side slope $>$ ditch $=$ 


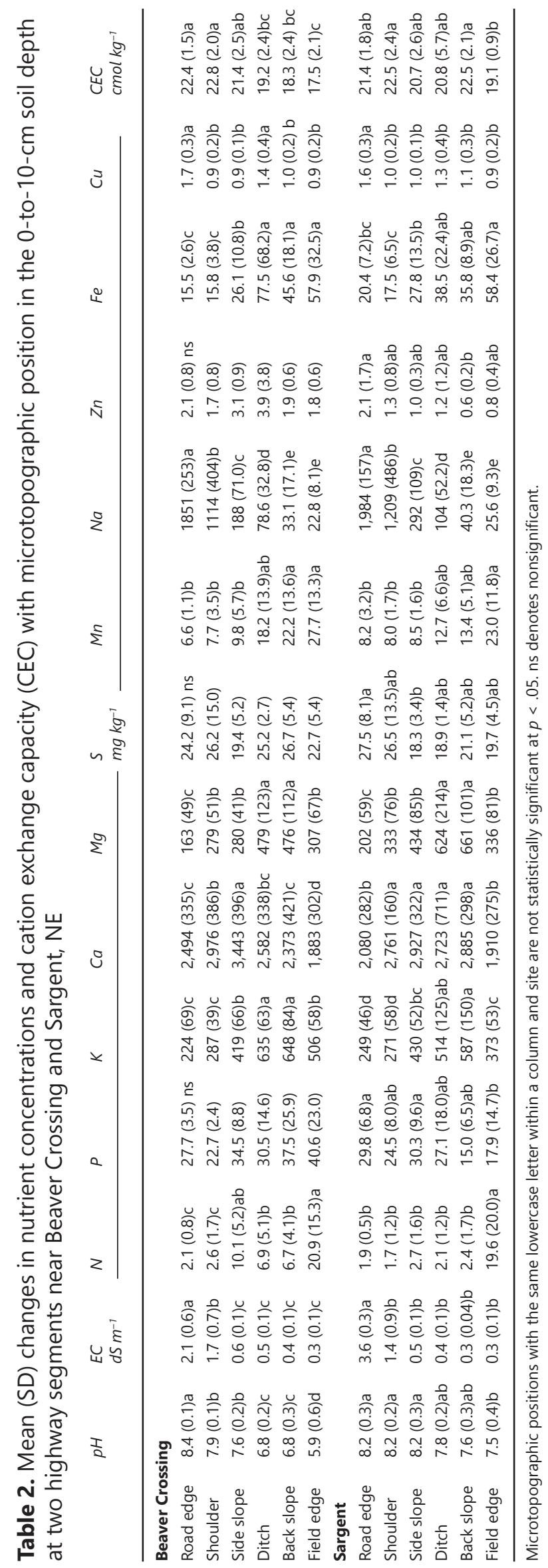


backslope $>$ field edge (7.49). At both sites, trends in soil $\mathrm{pH}$ for the 10-to-20-cm depth were similar to the upper depth. Changes in EC at the Beaver Crossing site for the 0 -to-10- $\mathrm{cm}$ depth paralleled the soil $\mathrm{pH}$ changes in the order: road edge $\left(2.08 \mathrm{dS} \mathrm{m}^{-1}\right)=$ shoulder $>$ side

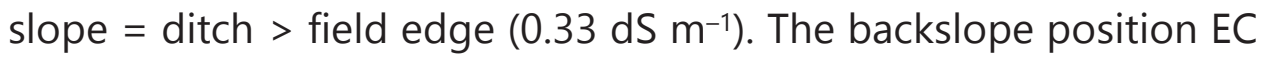
was similar to the side-slope, ditch, and field-edge positions. The response was similar at the Sargent site, but EC was higher at the roadedge position $\left(3.56 \mathrm{dS} \mathrm{m}^{-1}\right)$. At both sites, differences in EC among microtopographic positions were similar at the 10-to-20-cm depth (Supplemental Table S1).

Soil nutrient concentrations of N, K, Mg, Mn, and Fe were lower at the road edge than at the field-edge position (Table 2) for the 0-to10-cm depth at both sites. At the Beaver Crossing site, concentrations of $\mathrm{Ca}, \mathrm{Na}$, and $\mathrm{Cu}$ were higher at the road-edge position than at the field-edge position. The sideslope, ditch, and backslope positions had the highest concentrations of $\mathrm{K}, \mathrm{Ca}, \mathrm{Mg}$, and $\mathrm{Fe}$. The CEC generally decreased with increasing distance from the road-edge position. At the Sargent site, concentrations of $\mathrm{P}, \mathrm{Na}$, and $\mathrm{Cu}$ were higher, but those of $\mathrm{N}, \mathrm{K}, \mathrm{Mg}, \mathrm{Mn}$, and Fe were lower, at the road edge than at field-edge position for the 0 -to-10-cm depth. The sideslope, ditch, or backslope positions had the highest $\mathrm{K}, \mathrm{Ca}$, and $\mathrm{Mg}$ concentration. Organic matter (Table 3) concentration was lowest at the road-edge position and highest at the sideslope, ditch, and backslope positions at the Beaver Crossing site for the 0-to-10-cm depth. Similarly, at the Sargent site, organic matter was lower at the road edge than at the field-edge position. At both sites, organic matter concentration generally increased as the distance from the road increased.

At the 10-to-20-cm depth, Mg, Mn, Zn, Fe, and Cu concentrations did not vary with microtopographic position at both sites (Supplemental Table S1). Concentrations of $\mathrm{Ca}$ and $\mathrm{Na}$ and $\mathrm{CEC}$ were higher along the road-edge position than along the field-edge position at the Beaver Crossing site. Also, both $\mathrm{Ca}$ and $\mathrm{Na}$ concentration decreased with increasing distance from the road. Likewise, at the Sargent site, the concentrations of $\mathrm{Ca}$, $\mathrm{S}$, and $\mathrm{Na}$ and $\mathrm{CEC}$ were higher along the roadedge position than along the field-edge position. The concentration of $\mathrm{Na}$, similar to the surface depth, decreased with increasing distance from the road. At both sites, the road-edge position had lower organic matter concentration than the field-edge position for the 10-to-20-cm depth (Supplemental Table S2). 
Table 3. Mean (SD) changes in organic matter concentrations and select soil physical properties with microtopographic position in the 0 -to-10-cm soil depths at two highway segments near Beaver Crossing and Sargent, NE

\begin{tabular}{|c|c|c|c|c|c|}
\hline Position & $\begin{array}{l}\text { Organic matter } \\
\mathrm{g} \mathrm{kg-1}^{-1}\end{array}$ & $\begin{array}{l}\text { Bulk density } \\
\mathrm{Mg} \mathrm{m}^{-3}\end{array}$ & $\begin{array}{l}\text { Cone index } \\
\mathrm{MPa}\end{array}$ & $\begin{array}{l}\text { Macroaggregates } \\
\% s\end{array}$ & $\begin{array}{l}\text { Sorptivity } \\
\mathrm{cm}^{-1 / 2}\end{array}$ \\
\hline \multicolumn{6}{|c|}{ Beaver Crossing } \\
\hline Road edge & $16.3(0.4) d$ & $2.0(0.05) a$ & $6.8(2.1) a$ & $7.5(7.4) c$ & $0.2(0.1) c$ \\
\hline Shoulder & $24.4(0.5) c$ & $1.8(0.18) b$ & $5.1(1.9) b$ & $60.9(22.8) b$ & $0.2(0.1) c$ \\
\hline Side slope & $45.1(0.3) a$ & $1.4(0.05) \mathrm{c}$ & $2.1(0.6) c$ & $87.4(4.0) a$ & $0.9(0.3) a$ \\
\hline Ditch & $48.9(0.6) a$ & $1.2(0.18) d$ & $1.1(0.2) \mathrm{c}$ & $81.6(9.0) a$ & $0.9(0.3) a$ \\
\hline Back slope & $49.0(0.7) a$ & $1.6(0.11) \mathrm{cd}$ & $1.3(0.2) c$ & $86.1(5.5) a$ & na \\
\hline Field edge & $33.9(0.5) b$ & $1.4(0.29) \mathrm{cd}$ & $1.4(0.5) c$ & $64.6(9.3) b$ & $0.4(0.2) b$ \\
\hline \multicolumn{6}{|l|}{ Sargent } \\
\hline Road edge & $18.7(0.2) b$ & $1.7(0.04) a$ & $9.3(1.1) a$ & $15.5(9.2) d$ & $0.3(0.2) c$ \\
\hline Shoulder & $18.6(0.3) b$ & $1.5(0.16) b$ & $7.2(1.6) b$ & $23.3(12.3) \mathrm{dc}$ & $0.6(0.4) b$ \\
\hline Side slope & $24.5(0.3) b$ & $1.5(0.11) b$ & $5.0(1.8) \mathrm{c}$ & $33.6(16.8) c$ & $0.6(0.2) b$ \\
\hline Ditch & $26.3(0.6) b$ & $1.4(0.13) b c$ & $4.9(0.6) c$ & $50.9(26.1) b$ & $0.8(0.3) b$ \\
\hline Back slope & $32.0(0.4) a b$ & $1.3(0.10) b c$ & $3.2(2.2) d$ & 60.9 (18.3)ab & na \\
\hline Field edge & $39.1(0.2) a$ & $1.3(0.16) b c$ & $4.4(3.6) \mathrm{cd}$ & 63.5 (36.9)a & $1.2(0.6) a$ \\
\hline
\end{tabular}

Microtopographic positions with the same lowercase letter within a column and site are not statistically significant at $p<.05$. ns, nonsignificant.

Chloride and heavy metal concentrations were assessed on one transect from each side of the road; thus, no statistical analysis was conducted, and we only discuss numerical differences (Supplemental Table S3). At the Beaver Crossing site, there were numerical differences among positions for $\mathrm{Pb}$ only, where $\mathrm{Pb}$ was highest at the road-edge position. Chloride and all other heavy metals were generally similar in concentration among positions. At the Sargent site, there were numerical differences among positions for $\mathrm{Cl}, \mathrm{Cr}$, and $\mathrm{Pb}$ concentrations. Arsenic and $\mathrm{Cd}$ concentrations were similar across microtopographic position. Chloride concentration was highest at the road-edge, sideslope, and shoulder positions, generally decreasing with distance from the road. Chromium and $\mathrm{Pb}$ concentrations were highest at the shoulder positions, whereas all other positions were similar in concentration. Chloride concentrations were much higher at the Sargent site, likely due to the differences in soil texture and climatic conditions. 


\subsection{Soil physical properties}

Soil bulk density and cone index (compaction indicators), amount of water-stable macroaggregates (an indicator of changes in soil structure), and sorptivity (initial water infiltration) differed among the six microtopographic positions at both sites and depths $(0-10 \mathrm{~cm}$ and 10-20 cm) (Table 3). Bulk density decreased from the road edge (1.94 $\mathrm{Mg} \mathrm{m}^{-3}$ ) to the ditch $\left(1.23 \mathrm{Mg} \mathrm{m}^{-3}\right)$. The backslope and field-edge positions were similar to the side-slope and ditch positions at the 0 -to10- $\mathrm{cm}$ depth at the Beaver Crossing site, whereas at the same depth bulk density was higher at the road-edge position $\left(1.65 \mathrm{Mg} \mathrm{m}^{-3}\right) \mathrm{com}-$ pared with all other microtopographic positions (mean of all other positions, $1.38 \mathrm{Mg} \mathrm{m}^{-3}$ ) at the Sargent site. For the 10-to-20-cm depth, bulk density generally decreased with increasing distance from the road edge at both sites.

Similar to bulk density, cone index was highest at the road-edge position (6-9.5 MPa) and generally decreased with increasing distance from the road at both sites and depths. The lowest cone index values occurred at the side-slope, ditch, backslope, and field-edge positions at the Beaver Crossing site (mean, 1.6 MPa) and at the backslope and field-edge positions at the Sargent site (mean, 4.1 MPa). Macroaggregate amount was the lowest at the road-edge position (7\%) and highest at the side-slope, ditch, and backslope positions (85\%) at the Beaver Crossing site for the 0 -to-10-cm depth. For the same depth, macroaggregate amount was lowest at the road-edge position (15\%) and highest at the field-edge position (63\%) at the Sargent site. For the 10-to-20-cm depth, differences were similar to the upper depth at both sites (Supplemental Table S2).

Likewise, at both sites, soil sorptivity was lowest near the road and highest further away from the road. Sorptivity at the Beaver Crossing site was lowest at the road-edge and shoulder positions $(0.21 \mathrm{~cm}$ $\left.\mathrm{s}^{-1 / 2}\right)$ and highest at the side-slope and ditch positions $\left(0.9 \mathrm{~cm} \mathrm{~s}^{-1 / 2}\right)$. At the Sargent site, soil sorptivity was the lowest at the road-edge position $\left(0.25 \mathrm{~cm} \mathrm{~s}^{-1 / 2}\right)$ and highest at the field-edge position $\left(1.23 \mathrm{~cm} \mathrm{~s}^{-1 / 2}\right)$.

At Beaver Crossing, for the 0 -to- $10-\mathrm{cm}$ depth, gravel $>4.75 \mathrm{~mm}$ and gravel 4-4.75 $\mathrm{mm}$ were highest at the road-edge, ditch, and sideslope positions and minimal on the backslope and field-edge positions (Supplemental Table S4). Pebbles 2.38-4 mm and 2-2.38 mm 
generally decreased with increasing distance from the road. Soil textures were loam at the roadedge, side-slope, and ditch positions and silt loam at the shoulder, backslope, and field-edge positions. At Sargent, for the same depth, of the coarse material, gravel $>4.75 \mathrm{~mm}$ and pebbles 2.38-4 $\mathrm{mm}$ were most common on the road-edge, shoulder, and side-slope positions. Coarse material was generally not present in the ditch, backslope, and field-edge positions. Soil texture was generally sandy near the road and silt loam to loam from the side-slope to field-edge positions. At Beaver Crossing for the 10-to-20-cm depth, gravel and pebbles were typically present at the road-edge, shoulder, side slope, and ditch positions and absent at the backslope and field-edge position. For the same depth at Sargent, gravel $>4.75 \mathrm{~mm}$ and pebbles 2.38-4 $\mathrm{mm}$ were most common in the coarse material, particularly at the road-edge position. Soil texture was sandy at the road-edge position and loam to silt loam beginning at the shoulder position.

\subsection{Correlations among soil properties}

We studied correlations of soil properties across microtopographic positions for the 0-to-10-cm depth by site (Table 4). At the Beaver Crossing site, bulk density and cone index were strongly and negatively correlated with the amount of macroaggregates and organic matter, indicating that as soil compaction increased, both macroaggregation and organic matter accumulation decreased (Table 4). Similarly, an increase in $\mathrm{Na}$ concentration resulted in a reduced amount of macroaggregates. Soil sorptivity declined as bulk density, cone index, and Na concentration increased, but it improved with an increase in organic matter and in the amount of macroaggregates. Soil $\mathrm{pH}$ increased with increasing $\mathrm{Na}$ and decreasing organic matter concentrations. At the Sargent site, correlations were similar to those at the Beaver Crossing site except that sorptivity was not correlated with bulk density and organic matter and Na concentrations.

\section{Discussion}

Soil chemical properties such as $\mathrm{Na}$ concentration, EC, and $\mathrm{pH}$ were above optimum (Tables 1 and 2). The high $\mathrm{Na}$ concentration at the 
Table 4. Pearson correlation coefficients among select soil properties for the 0 -to-10-cm depth along two highway segments near Beaver Crossing and Sargent, NE

$\begin{array}{cccccccc}\text { Bulk } & \text { Cone } & \text { Macro- } & & \text { Electrical } & \text { Organic } & \mathrm{Na} \\ \text { density } & \text { index } & \text { aggregates } & \text { Sorptivity } & \mathrm{pH} & \text { conductivity } & \text { matter } & \text { concentration } \\ \mathrm{Mg} \mathrm{m}^{-3} & \mathrm{MPa} & \% & \mathrm{~S} \mathrm{~cm}^{-1 / 2} & \mathrm{dS} \mathrm{m}^{-1} & \mathrm{~g} \mathrm{~kg}^{-1} & \mathrm{mg} \mathrm{kg}^{-1} & \end{array}$

\section{Beaver Crossing}

Bulk density $\left(\mathrm{Mg} \mathrm{m}^{-3}\right)$

Cone index (MPa)

Macroaggregates (\%)

Sorptivity $\left(\mathrm{s} \mathrm{cm}^{-1 / 2}\right)$

$\mathrm{pH}$

Electrical conductivity (dS m-1)

Organic matter $\left(\mathrm{g} \mathrm{kg}^{-1}\right)$

Na concentration $\left(\mathrm{mg} \mathrm{kg}^{-1}\right)$

\section{Sargent}

Bulk density $\left(\mathrm{Mg} \mathrm{m}^{-3}\right)$

Cone index (MPa)

Macroaggregates (\%)

Sorptivity $\left(\mathrm{s} \mathrm{cm}^{-1 / 2}\right)$

$\mathrm{pH}$

Electrical conductivity ( $\mathrm{dS} \mathrm{m}^{-1}$ )

Organic matter $\left(\mathrm{g} \mathrm{kg}^{-1}\right)$

Na concentration $\left(\mathrm{mg} \mathrm{kg}^{-1}\right)$

$$
\begin{aligned}
& 1 \\
& 0.84^{* *} \quad 1 \\
& \begin{array}{llll}
-0.58^{*} & -0.57^{*} & 0.57^{* *} & 1
\end{array} \\
& 0.79^{* *} \quad 0.80^{* *} \quad-0.60^{* *} \quad-0.61^{*} \\
& 0.84^{\star *} \quad 0.87^{\star \star}
\end{aligned}
$$$$
-0.68^{* *}-0.59^{* *} \quad 1
$$$$
\begin{array}{llll}
0.61^{* *} & 0.73^{* *} & -0.21 & -0.33
\end{array}
$$$$
-0.81^{* *}-0.76^{\star *} \quad 0.77^{\star *} \quad 0.54^{*}
$$$$
-0.69 * *
$$$$
-0.63^{*}
$$

$$
\begin{array}{cc}
1 & \\
0.73^{\star *} & 1 \\
-0.53^{* *} & -0.77^{\star *} \\
0.78^{* *} & 0.96^{* *}
\end{array}
$$
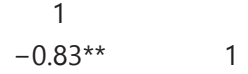

*Significant at the .05 probability level.

${ }^{* *}$ Significant at the .01 probability level.

road-edge position followed by the shoulder and side-slope positions is likely due to deicing salt application during winter road management. The estimated quantity of rock salt used for road deicing in the United States was about 24.5 million t in 2010 (Lilek, 2017), with application rates ranging from 14 to $169 \mathrm{~kg} \mathrm{~km}^{-1}$ of lane per pass (Blackburn and Associates, 2014). Although other deicing agents, such as $\mathrm{CaCl}_{2}$ can be used, rock salt $(\mathrm{NaCl})$ is the most commonly used (Blackburn and Associates, 2014). The accumulation of $\mathrm{Na}$ at these locations of the roadway can be toxic to sensitive plants and can reduce soil-water potential. Further, as shown by the correlations in Table 3, the high Na concentration can disperse soil aggregates, leading to smaller aggregate size, low water infiltration, and higher levels of compaction. At the road-edge position of these sites, the exchangeable Na concentration was about $36 \%$ at Beaver Crossing and $17 \%$ at Sargent, which is above the $15 \%$ exchangeable $\mathrm{Na}$ threshold for salt-sensitive plants (Tisdale, Nelson, Beaton, \& Havlin, 1993). Sodium causes issues within 
the soil and within plants as well. For example, high levels of $\mathrm{Na}$ can alter stomatal function and nutritional balance with $\mathrm{Ca}$ and $\mathrm{K}$ (Tavakkoli, Rengasamy, \& McDonald, 2010). Our results agree with those of a study in New York that showed 2.3 times higher Na concentrations near the road than the equivalent backslope, which was attributed to road salt application (Willmert et al., 2018). In urban soils, Na concentrations are generally $100 \mathrm{mg} \mathrm{kg}^{-1}$ higher near commercial or transportation centers $\left(214 \mathrm{mg} \mathrm{kg}^{-1}\right)$ than near residential or parkland areas (about $100 \mathrm{mg} \mathrm{kg}^{-1}$ ) (Pouyat, Yesilonis, Russell-Anelli, \& Neerchal, 2007). It should also be noted that urban areas with high salt (commercial and transportation) concentrations are substantially lower than our road-edge Na concentrations (Table 2) (Pouyat et al., 2007).

The high EC along the road edge (Table 2) is likely driven in part by the high $\mathrm{Na}$ concentration and is related to the high $\mathrm{pH}$ (Equiza, Calvo-Polanco, Cirelli, Señorans, \& Wartenbe, 2017). For example, across sites, the EC was 1.7-3.0 times above the threshold level (1.2

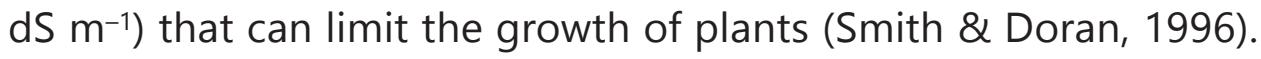
Our results of higher EC along the road edge are in line with those in North Dakota and New York (Matthees et al., 2018; Willmert et al., 2018). Therefore, based on our data, the concentration of Na followed by EC can be the primary soil chemical concerns for plant establishment and growth in these soils.

The high soil $\mathrm{pH}(>8)$ at the road edge may indicate lower availability of some nutrients and is outside the optimum $\mathrm{pH}$ range of 6.57.0 for most plants (Tisdale et al., 1993). One concern with the high $\mathrm{pH}$ and $\mathrm{Ca}$ concentration along the road edge is the amount of available Fe. Soils with $\mathrm{pH}$ levels of 7.3-8.5 are more likely to have plants showing Fe deficiency symptoms (Tisdale et al., 1993). However, the Fe concentrations of the soils along these two roadsides are above sufficiency thresholds $\left(>4.5 \mathrm{mg} \mathrm{kg}^{-1}\right)$. Previous studies in North Dakota and New York also showed decreasing $\mathrm{pH}$ with increasing distance from the road (Matthees et al., 2018; Willmert et al., 2018). In urban soils, soil pH may not be above 7 , although levels of Ca may be high in commercial or transportation and industrial centers compared with parks and residential areas (Pouyat et al., 2007). Thus, it appears that, although $\mathrm{pH}$ is high, other roadside soil properties appear to have much more negative effects on plant growth.

Results from the two road edges studied showed that compaction 
parameters (bulk density and particularly cone index) appear to be the leading soil physical properties limiting plant establishment and growth along the roadside coupled with aggregation, water infiltration, and the previously discussed chemical properties, all or most of which are interrelated (Table 2) (Equiza et al., 2017). For example, bulk density was 1.09 times higher at the road edge and 1.03 times higher at the shoulder position than the threshold level of $1.8 \mathrm{Mg} \mathrm{m}^{-3}$ (Table 1) (Weil \& Brady, 2017) at the Beaver Crossing site. Other microtopographic positions were below the threshold bulk density level at the Beaver Crossing site, and none of the microtopographic positions was above the threshold bulk density level at Sargent. Although the 1.03 to 1.08 times higher bulk density at Beaver Crossing may not alone restrict plant growth, other properties, such as the adverse chemical properties (Tables 1 and 2), may have greater adverse effects on plant growth.

Similarly, cone index values for the road edge and shoulder exceeded the threshold value of $2 \mathrm{MPa}$ (Table 1) (Tormena, Silva, \& Libardi, 1999) by at least three times at Beaver Crossing and five times at Sargent. The road-edge position adjacent to the road (about $1 \mathrm{~m}$ ) was highly compacted by road grading during construction and offroad vehicle traffic following construction, which can explain the reduced vegetation establishment along the roadsides. Our results agree with a study in New York where the road edge with reduced vegetation had higher bulk density compared with the soil in the backslope position (Willmert et al., 2018).

The amount of macroaggregates $(<15 \%)$ at the road edge of both sites was much lower than a threshold level of macroaggregates (66\%) observed in "ideal" agricultural soils with 4- 5\% organic matter (Table 1) (Ruis, Blanco-Canqui, Jasa, Ferguson, \& Slater, 2017; Weil \& Brady, 2017). The amount of macroaggregates and water infiltration were highest at the ditch and field edge, where we observed the tallest and most dense vegetation. Also, as shown by the correlations in Table 6, the decrease in sorptivity and the amount of aggregates with an increase in compaction parameters indicate that high levels of compaction can directly affect water infiltration and structural quality.

The low amount of macroaggregates and low rate of water infiltration combined with limited vegetation cover at the road-edge position may cause increased rates of runoff and losses of sediment and 
nutrients, thereby reducing water quality and contributing to further environmental degradation (Barrett et al., 2004; Streeter, Schilling, St. Clair, \& Demanett, 2019). Vegetation cover along roads have the potential to perform functions similar to filter strips. Our findings of lower water infiltration and aggregation near the road edge are similar to studies on loamy soils in Virginia and North Dakota, which reported that road edges and areas with construction traffic can have lower water infiltration (Matthees et al., 2018) and aggregation (Chen, Day, Wick, \& McGuire, 2014) than non-road edge or nontrafficked locations.

Concentrations of $\mathrm{Cl}$ and heavy metals were generally similar among the microtopographic positions, with some exceptions. The first exception is $\mathrm{Cl}$ at Sargent, which was highest at the road-edge, shoulder, and side-slope positions and could be a contributing factor to poor vegetation establishment at that site because high $\mathrm{Cl}$ concentrations degrade chlorophyll, resulting in poor growth under saline conditions (Tavakkoli et al., 2010). The second exception is Pb, which was highest at the road-edge position at the Beaver Crossing site and highest at the shoulder position at Sargent. Compared with urban soils, the concentration of $\mathrm{Pb}$ was much lower (Pouyat et al., 2007). The levels of other heavy metals at other microtopographic positions were likely not issues for plants because similar concentrations were observed where plant growth was abundant (i.e., the ditch), and none exceeded the toxicity limits in the established literature (Kabata-Pendias, 2011). Despite this fact, the high levels of $\mathrm{Na}$ and $\mathrm{Cl}$ at the road edge can increase the mobility of heavy metals, thus leading to the potential for contamination of ground and surface waters (Schuler \& Relyea, 2018).

Understanding how key soil fertility and physical properties differ among different microtopographic roadside positions is an important first step to identifying factors affecting roadside vegetation establishment. The use of remediation measures (Hillhouse, Schacht, Soper, \& Weinhold, 2018; Litalien \& Zeeb, 2020) and identification of salt- and compaction-tolerant plants (Friell, Watkins, \& Horgan, 2012; Hilvers, Hopkinson, \& Davis, 2017; Johnson, 2008) need to be investigated to successfully establish roadside vegetation in Nebraska. 


\section{Conclusion}

This study identified several properties that can limit vegetation establishment and growth along roadsides by comparing soil properties among microtopographic positions (road edge, shoulder, side slope, ditch, backslope, and field edge). Compaction, Na concentration, EC, and $\mathrm{pH}$ were highest at the road-edge position and decreased with increasing distance from the road; these have cascading effects on plant establishment and growth. Likewise, water infiltration and aggregation were lowest at the road-edge position but improved with distance from the road. Compaction parameters, Na concentration, and EC were above the threshold levels for compaction, sodicity, and salt-sensitive plants. Based on the correlation analysis, high levels of compaction reduced the amount of macroaggregates, water infiltration, and organic matter, whereas high $\mathrm{Na}$ concentration reduced the amount of macroaggregates, reduced water infiltration, and increased EC. Mitigation of compaction and sodic conditions needs to be considered if delivery of ecosystem services from roadside vegetation is a priority. This study identified compaction and $\mathrm{Na}$ concentration as two of the leading soil physical and chemical properties that may be limiting vegetation establishment along roadsides in Nebraska.

Acknowledgments The authors wish to thank Jenna Beckman, Carolyn Fox, Matt Judkins, Leonard Kibet, Paul Koerner, and Brian Maust for field and laboratory assistance. This project was supported by the Nebraska Department of Transportation and the University of Nebraska-Lincoln Agricultural Research Division.

Conflict of interest The authors have declared there are no conflicts of interest.

\section{References}

Adriano, D., \& Doner, H. E. (1982). Bromine, chlorine, and fluorine. In A. L. Page, R. H. Miller, \& D. R. Keeney (Eds.), Methods of soil analysis. Part 2. Chemical and microbiological properties (2nd ed., pp. 449-479). Madison, WI: ASA and SSSA.

Akbar, K. F., Hale, W. H. G., \& Headley, A. D. (2003). Assessment of scenic beauty of the roadside vegetation in northern England. Landscape Urban Planning, 63, 139-144. http://doi.org/10.1016/S0169-2046(02)00185-8 
Baker, D. E., \& Amacher, M. C. (1982). Nickel, copper, zinc, and cadmium. In A. L. Page, R. H. Miller, \& D. R. Keeney (Eds.), Methods of soil analysis. Part 2. Chemical and microbiological properties (2nd ed., pp. 323-334). Madison, WI: ASA and SSSA.

Barrett, M., Lantin, A., \& Austrheim-Smith, S. (2004). Storm water pollutant removal in roadside vegetated buffer strips. Transportation Research Record, 1890, 129-140. http://doi.org/10.3141/1890-16

Blackburn and Associates. (2014). Clear Roads Study: Establishing effective salt and anti-icing application rates task 2: Update guidelines. Retrieved from https:// clearroads.org/project/12-02

Blake, G. R., \& Hartge, K. H. (1986). Bulk density. In A. Klute (Ed.), Methods of soil analysis. Part 1. Physical and mineralogical methods (pp. 363-375). Madison, WI: SSSA.

Blanco-Canqui, H., Lal, R., Owens, L. B., Post, W. M., \& Izaurralde, R. C. (2006). Corn stover impacts on near-surface soil properties of no-till corn in Ohio. Soil Science Society of America Journal, 70, 266- 278. http://doi.org/10.2136/ sssaj2005.0137

Bryson, G. M., \& Barker, A. V. (2002). Sodium accumulation in soils and plants along Massachusetts roadsides. Communications in Soil Science and Plant Analysis, 33, 67-78. http://doi.org/10.1081/CSS-120002378

Burau, R. G. (1982). Lead. In A. L. Page, R. H. Miller, \& D. R. Keeney (Eds.), Methods of soil analysis. Part 2. Chemical and microbiological properties (2nd ed., pp. 347-362). Madison, WI: ASA and SSSA.

Busscher,W. J., Bauer, P. J., Camp, C. R., \& Sojka, R. E. (1997). Correction of cone index for soil water content differences in a coastal plain soil. Soil and Tillage Research, 43, 205-217. http://doi.org/10.1016/S0167-1987(97)00015-9

Chen, U., Day, S. D., Wick, A. F., \& McGuire, K. J. (2014). Influence of urban land development and subsequent soil rehabilitation on soil aggregates, carbon, and hydraulic conductivity. Science of the Total Environment, 494-495, 329-336. http://doi.org/10.1016/j.scitotenv.2014.06.099

Daniels, J., Kimmel, C., McClung, S., Epstein, S., Bremer, J., \& Rossetti, K. (2018). Better understanding the potential importance of Florida roadside breeding habitat for the monarch. Insects, 9, 137. http://doi.org/10.3390/insects 9040137

Forman, R. T. T., Sperling, D., Bissonette, J. A., Clevenger, A. P., Cutshall, C. D., Dale, V. H., ... Winter, T. C. (2003). Road ecology: Science and solutions. Washington, DC: Island Press.

Frank, K., Beegle, D.,\&Denning, J. (2011). Phosphorus: Recommended chemical soil test procedures for the North Central Region. In Recommended chemical soil test procedures for the North Central Region (pp. 21-29). Columbia: Missouri Agricultural Experiment Station, University of Missouri.

Friell, J., Watkins, E., \& Horgan, B. (2012). Salt tolerance of $75 \mathrm{cool}$ season turfgrasses for roadsides. Acta Agriculturae Scandinavica, Section B-Soil Plant Science, 62(Suppl. 1), 44-52. http://doi.org/10.1080/09064710.2012.678381 
Equiza, M. A., Calvo-Polanco, M., Cirelli, D., Señorans, J., Wartenbe, M., Saunders, C., \& Zwiazek, J. J. (2017). Long-term impact of road salt ( $\mathrm{NaCl}$ ) on soil and urban trees in Edmonton, Canada. Urban Forestry \& Urban Greening, 21, 16-28. https://doi.org/10.1016/j.ufug.2016.11.003

Ganje, T. J., \& Rains, D.W. (1982). Arsenic. In A. L. Page, R. H. Miller, \& D. R. Keeney (Eds.), Methods of soil analysis. Part 2. Chemical and microbiological properties (2nd ed., pp. 385-400).Madison, WI: ASA and SSSA.

Gee, G. W., \& Bauder, J. W. (1986). Particle-size analysis. In A. Klute (Ed.), Methods of soil analysis. Part I: Physical and mineralogical methods (pp. 383-411). Madison, WI: SSSA.

Gelderman, R. H., \& Beegle, D. (2011). Nitrate-nitrogen. In Recommended chemical soil test procedures for the North Central Region (pp. 17-20). Columbia: Missouri Agricultural Experiment Station, University of Missouri.

Haan, N. L., Hunter, M. R., \& Hunter, M. D. (2012). Investigating predictors of plant establishment during roadside restoration. Restoration Ecology, 20, 315-321. http://doi.org/10.1111/j.1526-100X.2011.00802.x

Hillhouse, H. L., Schacht,W. H., Soper, J. M., \&Weinhold, C. E. (2018). Effects of nitrogen and phosphorus fertilizer and topsoil amendment on native plant cover in roadside revegetation projects. Environmental Management, 61, 14714. http://doi.org/10.1007/s00267-017-0946-9

Hilvers, G., Hopkinson, L., \& Davis, E. (2017). Evaluation of revegetation techniques for roadside construction sites. Journal of Environmental Engineering and Landscape Management, 25, 305-315. http://doi.org/10.3846/16486897.2016.1 $\underline{259166}$

Johnson, A. (2008). Best practices handbook for roadside vegetation management. St. Paul, MN: Office of Research Services-Minnesota Department of Transportation.

Jumikis, A. (1979). About snow drifts. Retrieved from http://trid.trb.org/view/86425

Kabata-Pendias, A. (2011). Trace elements in soils and plants (4th ed). Boca Raton, FL: CRC Press.

Kasten, K., Stenolen, C., Caldwell, W., \& Oberhauser, K. S. (2016). Can roadside habitat lead monarchs on a route to recover? Journal of Insect Conservation, 20, 1047-1057. http://doi.org/10.1007/s10841-016-9938-y

Lilek, J. (2017). Roadway deicing in the United States. American Geosciences Institute factsheet. Retrieved from https://www.americangeosciences.org/sites/ default/files/Cl Factsheet 20173 Deicing 170712.pdf

Litalien, A., \& Zeeb, B. (2020). Curing the earth: A review of anthropogenic soil salinization and plant-based strategies for sustainable mitigation. Science of the Total Environment, 698, 134235. http://doi.org/10.1016/j.scitotenv.2019.134235

Lowery, B., \& Morrison, J. E. (2002). Soil penetrometers and penetrability. In J. H. Dane \& G. C. Topp (Eds.), Methods of soil analysis. Part 4. Physical methods (pp. 363-385). Madison, WI: SSSA.

Matthees, H. L., Hopkins, D. G., \& Casey, F. X.M. (2018). Soil property distribution following oil well access road removal in North Dakota. Canadian Journal of Soil Science, 98, 369-380. http://doi.org/10.1139/cjss-2017-0141 
McCleery, R. A., Holdorf, A. R., Hubbard, L. L., \& Peer, B. D. (2015). Maximizing the wildlife conservation value of road right-of-ways in an agriculturally dominated landscape. PLOS ONE, 10, e0120375. http://doi.org/10.1371/journal. pone.0120375

Neher, D. A., Asmussen, D., \& Lovell, S. T. (2013). Roads in northern hardwood forests affect adjacent plant communities and soil chemistry in proportion to the maintained roadside area. Science of the Total Environment, 449, 320-327. http://doi.org/10.1016/j.scitotenv.2013.01.062

Nelson, D. W., \& Sommers, L. E. (1996). Total carbon, organic carbon, and organic matter analysis. In D. L. Sparks, A. L. Page, P. A. Helmke, R. H. Loeppert, P. N. Soltanpour, M. A. Tabatabai, C. T. Johnston, \& M. E. Sumner (Eds.), Methods of soil analysis. Part 3. Chemical methods (pp. 961-1010). Madison, WI: SSSA.

Nimmo, J. R., \& Perkins, K. S. (2002). Aggregate stability and size distribution. In J. H. Dane \& G. C. Topp (Eds.), Methods of soil analysis. Part 4. Physical methods (pp. 317-328). Madison, WI: SSSA.

Ozdemir, H. (2019). Mitigation impact of roadside trees on fine particle pollution. Science of the Total Environment, 659, 1176-1185. http://doi.org/10.1016/j. scitotenv.2018.12.262

Pouyat, R. V., Yesilonis, I. D., Russell-Anelli, J., \& Neerchal, N. K. (2007). Soil chemical and physical properties that differentiate urban land-use and cover types. Soil Science Society of America Journal, 71, 1010-1019. http://doi. org/10.2136/sssaj2006.0164

Reisenauer, H. M. (1982). Chromium. In A. L. Page, R. H. Miller, \& D. R. Keeney (Eds.), Methods of soil analysis. Part 2. Chemical and microbiological properties (2nd ed., pp. 337-344).Madison, WI: ASA and SSSA.

Ruis, S., Blanco-Canqui, H., Jasa, P., Ferguson, R., \& Slater, G. (2017). Can cover crop use allow increased levels of corn residue removal for biofuel in irrigated and rainfed systems? BioEnergy Research, 10, 992-1004. http://doi. org/10.1007/s12155-017-9858-z

SAS Institute. (2019). SAS OnlineDoc 9.1.3. Retrieved from http://support.sas.com/ onlinedoc/913/docMainpage.jsp

Schuler,M. S., \& Relyea, R. A. (2018). A review of the combined threats of road salts and heavy metals to freshwater systems. BioScience, 68, 327-335. http:// doi.org/10.1093/biosci/biy018

Smith, R. E. (1999). Technical note: Rapid measurement of soil sorptivity. Soil Science Society of America Journal, 63, 55-57. http://doi.org/10.2136/sssaj1999. 03615995006300010009x

Smith, J. L., \& Doran, J. W. (1996). Measurement and use of $\mathrm{pH}$ and electrical conductivity for soil quality analysis. In J.W. Doran \& A. J. Jones (Eds.), Methods for assessing soil quality (pp. 169-185).Madison, WI: SSSA.

Streeter, M. T., Schilling, K. E., St. Clair, M., \& Demanett, Z. (2019). Soil sedimentation and quality within the roadside ditches of an agricultural watershed. Science of the Total Environment, 657, 1432-1440. http://doi. org/10.1016/j.scitotenv.2018.12.113 
Sumner, M. E., \& Miller, W. P. (1996). Cation exchange capacity, and exchange coefficients. In D. L. Sparks (Ed.), Methods of soil analysis. Part 2. Chemical properties (3rd ed., 1201-1229). Madison, WI: ASA, SSSA, and CSSA.

Tavakkoli, E., Rengasamy, P., \& McDonald, G. K. (2010). High concentrations of $\mathrm{Na}^{+}$and $\mathrm{Cl}^{-}$ions in soil solution have simultaneous detrimental effects on growth of faba bean under salinity stress. Journal of Experimental Botany, 61, 4449-4459.

Tisdale, S. L., Nelson, W. L., Beaton, J. D., \& Havlin, J. L. (1993). Soil fertility and fertilizers. New York: Macmillan.

Tormena, C.A., Silva, A. P., \& Libardi, P. L. (1999). Soil physical quality of a Brazilian Oxisol under two tillage systems using the least limiting water range approach. Soil and Tillage Research, 52, 223-232. http://doi.org/10.1016/ S0167-1987(99)00086-0

Warncke, D., \& Brown, J. R. (2011). Potassium and other basic cations. In Recommended chemical soil test procedures for the North Central Region (pp. 31-34). Fargo: North Dakota Agricultural Experiment Station, North Dakota State University.

Weil, B. R., \& Brady, N. C. (2017). The nature and properties of soils. Boston, MA: Pearson.

Whitney, D.A. (2011b). Micronutrients: Zinc, iron, manganese, and copper. In Recommended chemical soil test procedures for the North Central Region (pp. 41-44). Fargo: North Dakota Agricultural Experiment Station, North Dakota State University.

Whitney, D. A. (2011a). Soil salinity. In Recommended chemical soil test procedures for the North Central Region (pp. 59-60). Fargo: North Dakota Agricultural Experiment Station, North Dakota State University.

Willmert, H. M., Osso, J. D., Jr., Twiss, M. R., \& Langen, T. A. (2018). Winter road management effects on roadside soil and vegetation along a mountain pass in the Adirondack Park, New York, USA. Journal of Environmental Management, 225, 215-223. http://doi.org/10.1016/j.jenvman.2018.07.085

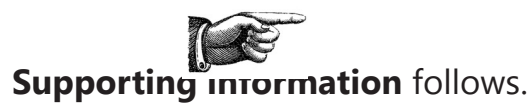


Supplementary Table 1. Mean (SD) changes in nutrient concentrations and cation exchange capacity (CEC) with micro-topographic position in the 0 to 10 and 10 to $20 \mathrm{~cm}$ soil depths at two highway segments near Beaver Crossing and Sargent, NE. Micro-topographic positions with the same lowercase letter within a column and site are not statistically significant at $p<0.05$. ns denotes non-significant.

\begin{tabular}{|c|c|c|c|c|c|c|c|c|c|c|c|c|c|c|}
\hline & pH & EC & $\mathbf{N}$ & $\mathbf{P}$ & $\mathbf{K}$ & $\mathbf{C a}$ & Mg & $\mathbf{S}$ & Mn & $\mathrm{Na}$ & $\mathbf{Z n}$ & $\mathbf{F e}$ & $\mathbf{C u}$ & CEC \\
\hline & \multicolumn{13}{|c|}{$\left(\mathrm{mg} \mathrm{kg}^{-1}\right)$} & $\left(\mathrm{cmol} \mathrm{kg}^{-1}\right)$ \\
\hline & \multicolumn{14}{|c|}{10 to $20 \mathrm{~cm}$ soil depth } \\
\hline & \multicolumn{14}{|c|}{ Beaver Crossing } \\
\hline Road edge & $7.9(0.5) \mathrm{a}$ & $2.5(2.7) \mathrm{a}$ & $5.6(5.0) \mathrm{ns}$ & $\begin{array}{l}21.8(10.8) \\
\mathrm{ab}\end{array}$ & $\begin{array}{l}342 \\
(128) b\end{array}$ & $\begin{array}{l}4445(701) \\
\mathrm{a}\end{array}$ & $\begin{array}{l}351(206) \\
n s\end{array}$ & $\begin{array}{l}42.8(25.5) \\
\mathrm{a}\end{array}$ & $6.5(2.0) \mathrm{ns}$ & \multirow{3}{*}{$\begin{array}{l}1365(774) \mathrm{a} \\
452(413) \mathrm{b}\end{array}$} & $1.4(1.2) \mathrm{ns}$ & $13.9(5.9) \mathrm{ns}$ & $\begin{array}{l}0.8(0.2) \\
\text { ns }\end{array}$ & $32.0(7.4) \mathrm{a}$ \\
\hline Shoulder & $\begin{array}{l}7.8(0.2) \\
a b\end{array}$ & $1.9(1.3) \mathrm{b}$ & $8.6(7.8)$ & $\begin{array}{l}36.9(18.3) \\
\mathrm{a}\end{array}$ & $\begin{array}{l}500(75) \\
\mathrm{a}\end{array}$ & $\begin{array}{l}3660(491) \\
a b\end{array}$ & $394(115)$ & $16.2(8.5) \mathrm{b}$ & $6.2(1.2)$ & & $1.9(1.5)$ & $10.8(3.8)$ & $0.8(0.1)$ & $24.8(3.9) \mathrm{b}$ \\
\hline Side slope & $7.5(0.3) b$ & $0.5(0.3) \mathrm{c}$ & $5.7(3.4)$ & $\begin{array}{l}36.0(22.0) \\
\mathrm{a}\end{array}$ & $\begin{array}{l}511(30) \\
\mathrm{a}\end{array}$ & $\begin{array}{l}3564(698) \\
a b\end{array}$ & $365(64)$ & $16.9(7.9) \mathrm{b}$ & $6.2(1.7)$ & & $1.9(1.2)$ & $11.3(2.8)$ & $0.8(0.1)$ & $23.0(3.3) \mathrm{b}$ \\
\hline Ditch & $6.8(0.5) \mathrm{c}$ & $0.3(0.1) \mathrm{c}$ & $7.7(4.1)$ & $\begin{array}{l}20.8(12.4) \\
\mathrm{ab}\end{array}$ & $\begin{array}{l}489(70) \\
\mathrm{a}\end{array}$ & $\begin{array}{l}3143(835) \\
\text { bc }\end{array}$ & $367(84)$ & $14.8(7.9) \mathrm{b}$ & $6.7(3.1)$ & $\begin{array}{l}194(194) \mathrm{c} \\
54.7(28.3) \mathrm{d}\end{array}$ & $1.1(0.3)$ & $15.2(11.4)$ & $0.8(0.2)$ & $20.3(4.5) b c$ \\
\hline Back slope & $6.6(0.6) \mathrm{c}$ & $0.3(0.1) \mathrm{c}$ & $5.7(4.0)$ & $13.5(7.6) b$ & $\begin{array}{l}454(86) \\
a\end{array}$ & $\begin{array}{l}2971 \\
(1067) b c\end{array}$ & $382(15)$ & $14.3(7.3) \mathrm{b}$ & $7.1(3.1)$ & \multirow{2}{*}{$\begin{array}{l}21.7(107) \mathrm{e} \\
12.3(6.1) \mathrm{e} \\
\end{array}$} & $0.9(0.3)$ & $16.1(9.6)$ & $0.8(0.2)$ & $19.3(5.7) \mathrm{bc}$ \\
\hline Field edge & $5.5(0.2) \mathrm{d}$ & $0.3(0.1) \mathrm{c}$ & $6.0(3.9)$ & $8.5(4.1) b$ & $\begin{array}{l}459 \\
(156) \mathrm{a}\end{array}$ & $\begin{array}{l}2322(530) \\
\mathrm{c}\end{array}$ & $328(112)$ & $\begin{array}{l}18.0(10.7) \\
\mathrm{b}\end{array}$ & $7.5(1.3)$ & & $1.6(0.9)$ & $13.7(4.8)$ & $0.7(0.03)$ & $15.6(3.7) \mathrm{c}$ \\
\hline Road edge & $8.2(0.2) \mathrm{a}$ & $2.0(0.8) \mathrm{a}$ & $4.7(2.8) \mathrm{ab}$ & $\begin{array}{l}17.3(5.8) \\
a b\end{array}$ & $\begin{array}{l}398(74) \\
\text { ns }\end{array}$ & $\begin{array}{l}4243(811) \\
\mathrm{a}\end{array}$ & $\begin{array}{l}308(91) \\
\text { ns }\end{array}$ & $\begin{array}{l}\text { Sargent } \\
51.7(57.9) \\
\mathrm{a}\end{array}$ & $5.4(0.9) \mathrm{ns}$ & \multirow{3}{*}{$\begin{array}{l}741(351) \mathrm{a} \\
329(233) \mathrm{b}\end{array}$} & $1.2(0.7) b c$ & $15.6(5.6) \mathrm{ns}$ & $\begin{array}{l}0.8(0.2) \\
\text { ns }\end{array}$ & $28.0(4.3) \mathrm{a}$ \\
\hline Shoulder & $\begin{array}{l}8.1(0.4) \\
\mathrm{ab}\end{array}$ & $1.1(1.0) \mathrm{b}$ & $6.6(7.4) \mathrm{ab}$ & $\begin{array}{l}35.0(27.1) \\
\mathrm{ab}\end{array}$ & $\begin{array}{l}402 \\
(103)\end{array}$ & $\begin{array}{l}3233(685) \\
b\end{array}$ & $363(105)$ & $15.5(4.0) \mathrm{b}$ & $7.2(3.2)$ & & $2.2(1.5) \mathrm{ab}$ & $14.9(5.3)$ & $0.8(0.1)$ & $21.7(4.5) b$ \\
\hline Side slope & $\begin{array}{l}8.2(0.3) \\
\text { ab }\end{array}$ & $0.6(0.4) b c$ & $7.8(4.9) \mathrm{a}$ & $\begin{array}{l}39.9(33.5) \\
\mathrm{a}\end{array}$ & $432(58)$ & $\begin{array}{l}3069(655) \\
b\end{array}$ & 367 (71) & $17.4(9.5) \mathrm{b}$ & $5.2(1.0)$ & & $2.7(1.8) \mathrm{a}$ & $13.7(4.5)$ & $0.8(0.1)$ & $20.3(4.0) \mathrm{b}$ \\
\hline Ditch & $\begin{array}{l}8.0(0.6) \\
\mathrm{ab}\end{array}$ & $0.3(0.1) \mathrm{c}$ & $3.9(3.5) \mathrm{ab}$ & $\begin{array}{l}17.3(10.8) \\
b\end{array}$ & $444(91)$ & $\begin{array}{l}3261 \\
(1057) b\end{array}$ & $390(108)$ & $\begin{array}{l}15.3(11.8) \\
\mathrm{b}\end{array}$ & $6.6(4.1)$ & $\begin{array}{l}181(127) \mathrm{b} \\
67.1(34.1) \mathrm{c}\end{array}$ & $0.7(0.1) \mathrm{c}$ & $13.0(5.0)$ & $0.8(0.2)$ & $21.0(5.6) b$ \\
\hline Back slope & $\begin{array}{l}7.7(0.7) \\
\text { bc }\end{array}$ & $0.2(0.1) \mathrm{c}$ & $2.7(1.3) b$ & $10.8(5.4) b$ & $418(58)$ & $\begin{array}{l}2885 \\
(1067) b\end{array}$ & $421(148)$ & $13.0(8.5) \mathrm{b}$ & $7.2(4.0)$ & $19.0(5.2) \mathrm{d}$ & $0.6(0.1) \mathrm{c}$ & $14.4(6.9)$ & $0.9(0.2)$ & $19.1(5.8) b$ \\
\hline Field edge & $\begin{array}{l}7.5(0.4) \\
\mathrm{bc}\end{array}$ & $0.2(0.1) \mathrm{c}$ & $3.0(1.0) \mathrm{ab}$ & $7.9(4.9) \mathrm{b}$ & $\begin{array}{l}411 \\
(149)\end{array}$ & $\begin{array}{l}2371(609) \\
\mathrm{b}\end{array}$ & 341 (76) & $14.7(7.9) \mathrm{b}$ & $8.1(2.9)$ & $12.4(7.1) \mathrm{d}$ & $0.7(0.2) \mathrm{c}$ & $12.4(4.7)$ & $0.7(0.04)$ & $15.8(3.6) b$ \\
\hline
\end{tabular}


Supplementary Table 2. Mean (SD) changes in organic matter concentrations and select soil physical properties with micro-topographic position in the 0 to 10 and 10 to $20 \mathrm{~cm}$ soil depths at two highway segments near Beaver Crossing and Sargent, NE. Micro-topographic positions with the same lowercase letter within a column and site are not statistically significant at $p<0.05$. ns denotes non-significant.

\begin{tabular}{|c|c|c|c|c|}
\hline & $\begin{array}{r}\text { Organic Matter } \\
\left(\mathrm{g} \mathrm{kg}^{-1}\right)\end{array}$ & $\begin{array}{r}\text { Bulk Density } \\
\left(\mathrm{Mg} \mathrm{m}^{-3}\right)\end{array}$ & $\begin{array}{r}\text { Cone Index } \\
\text { (MPa) }\end{array}$ & $\begin{array}{r}\text { Macroaggregates } \\
(\%)\end{array}$ \\
\hline & \multicolumn{4}{|c|}{10 to $20 \mathrm{~cm}$ soil depth } \\
\hline Road edge & $14.4(0.7) \mathrm{d}$ & $2.0(0.05) \mathrm{a}$ & $5.9(1.8) \mathrm{a}$ & $16.6(13.0) \mathrm{c}$ \\
\hline Shoulder & $20.7(0.7) \mathrm{cd}$ & $1.7(0.13) b$ & $4.3(1.6) \mathrm{a}$ & $45.4(4.5) b$ \\
\hline Side slope & $22.9(0.9) b c$ & $1.7(0.07) \mathrm{b}$ & $2.1(0.8) b$ & $74.7(2.7) \mathrm{a}$ \\
\hline Ditch & $18.7(1.1) \mathrm{cd}$ & $1.4(0.23) \mathrm{c}$ & $1.4(0.3) \mathrm{b}$ & $71.0(4.5) \mathrm{a}$ \\
\hline Back slope & $26.6(1.4) \mathrm{ab}$ & $1.5(0.04) \mathrm{c}$ & $1.6(0.2) b$ & $75.5(2.8) \mathrm{a}$ \\
\hline \multirow[t]{2}{*}{ Field edge } & $28.4(0.9) \mathrm{a}$ & $1.4(0.22) \mathrm{c}$ & $2.0(0.4) \mathrm{b}$ & $51.1(2.0) \mathrm{b}$ \\
\hline & \multicolumn{4}{|c|}{ Sargent } \\
\hline Road edge & $18.1(0.8) \mathrm{b}$ & $1.6(0.08) \mathrm{a}$ & $9.7(0.2) \mathrm{a}$ & $18.5(15.5) \mathrm{d}$ \\
\hline Shoulder & $20.3(0.8) \mathrm{ab}$ & $1.6(0.10) \mathrm{a}$ & $8.2(2.9) \mathrm{ab}$ & $36.4(26.0 \mathrm{c}$ \\
\hline Side slope & $26.5(1.2) \mathrm{a}$ & $1.5(0.16) \mathrm{ab}$ & $6.6(2.2) b c$ & $46.1(26.7) \mathrm{b}$ \\
\hline Ditch & $17.7(0.4) \mathrm{b}$ & $1.5(0.04) \mathrm{a}$ & $5.9(1.1) \mathrm{cd}$ & $51.8(22.7) \mathrm{b}$ \\
\hline Back slope & $20.8(0.7) \mathrm{ab}$ & $1.3(0.12) \mathrm{c}$ & $3.7(2.5) \mathrm{d}$ & $50.9(20.8) \mathrm{b}$ \\
\hline Field edge & $25.7(0.4) \mathrm{ab}$ & $1.4(0.07) \mathrm{bc}$ & $5.3(3.7) \mathrm{d}$ & $64.4(24.8) \mathrm{a}$ \\
\hline
\end{tabular}


Supplementary Table 3. Mean (SD) chloride and heavy metal concentrations for the 0 to $10 \mathrm{~cm}$ depth along two highway segments near Beaver Crossing and Sargent, NE. No statistical analysis was run to compare concentrations at different road edge segments because only two transects were analyzed.

\begin{tabular}{lllcccc}
\hline & Chloride & Chromium & Nickel & Arsenic & Cadmium & Lead \\
\cline { 2 - 6 } & \multicolumn{5}{c}{$\left(\mathbf{m g ~ k g}^{-1}\right)$} \\
Road edge & $17.0(0.6)$ & $47.2(2.4)$ & $18.3(8.1)$ & $4.7(0.1)$ & $0.4(0)$ & $59.2(63.3)$ \\
Shoulder & $30.6(4.9)$ & $36.6(6.7)$ & $20.0(4.8)$ & $7.3(1.4)$ & $0.4(0)$ & $16.7(1.8)$ \\
Side Slope & $26.4(14.7)$ & $44.8(1.6)$ & $20.2(1.6)$ & $6.0(0.4)$ & $0.4(0.1)$ & $14.9(4.0)$ \\
Ditch & $39.0(9.7)$ & $35.9(10.9)$ & $19.1(5.1)$ & $6.7(0.80)$ & $0.3(0.04)$ & $14.6(0.3)$ \\
Backslope & $38.7(0.8)$ & $39.1(5.7)$ & $21.0(1.6)$ & $7.6(0.02)$ & $0.3(0.01)$ & $15.8(1.0)$ \\
Field Edge & $23.5(0)$ & $40.7(3.2)$ & $21.2(2.1)$ & $7.8(0.7)$ & $0.3(0.03)$ & $17.1(1.5)$ \\
& & \multicolumn{7}{c}{ Sargent } & & \\
Road edge & $1935(2729)$ & $32.4(3.6)$ & $15.0(2.6)$ & $3.5(0.6)$ & $0.15(0)$ & $7.7(1.9)$ \\
Shoulder & $448(624)$ & $51.6(10.5)$ & $16.5(4.4)$ & $3.4(0.5)$ & $0.15(0.01)$ & $76.1(86.8)$ \\
Side Slope & $217(136)$ & $28.3(0.4)$ & $13.4(1.7)$ & $3.1(0.9)$ & $0.16(0.03)$ & $13.0(3.3)$ \\
Ditch & $14.0(3.6)$ & $27.3(1.1)$ & $11.7(0.4)$ & $4.0(0.6)$ & $0.19(0.01)$ & $13.4(3.4)$ \\
Backslope & $9.9(3.0)$ & $25.0(1.1)$ & $10.6(0.1)$ & $4.1(0.8)$ & $0.19(0.04)$ & $11.9(3.9)$ \\
Field Edge & $10.7(7.6)$ & $25.0(0.02)$ & $10.8(0.4)$ & $4.4(0.5)$ & $0.22(0.09)$ & $12.3(4.2)$ \\
\hline
\end{tabular}


Supplementary Table 4. Mean (SD) coarse material (gravel, pebbles), sand, silt, clay percentages and soil texture for the 0 to $10 \mathrm{~cm}$ and 10 to 20 $\mathrm{cm}$ depths along two highway segments near Beaver Crossing and Sargent, NE.

\begin{tabular}{|c|c|c|c|c|c|c|c|c|}
\hline & $\begin{array}{l}\text { Gravel } \\
>4.75 \mathrm{~mm}\end{array}$ & $\begin{array}{l}\text { Gravel } 4 \\
\text { to } 4.75 \\
\text { mm }\end{array}$ & $\begin{array}{l}\text { Pebbles } 2.38 \\
\text { to } 4 \mathrm{~mm}\end{array}$ & $\begin{array}{l}\text { Pebbles } 2 \\
\text { to } 2.38 \mathrm{~mm}\end{array}$ & Sand & Silt & Clay & $\begin{array}{l}\text { Soil } \\
\text { Texture }\end{array}$ \\
\hline \multicolumn{9}{|c|}{$(\%)$} \\
\hline \multicolumn{9}{|c|}{0 to $10 \mathrm{~cm}$} \\
\hline \multicolumn{9}{|c|}{ Beaver Crossing } \\
\hline Road edge & $11.9(7.1)$ & $5.9(0.1)$ & $18.7(0.6)$ & $7.7(0.6)$ & $34.6(8.7)$ & $42.4(3.5)$ & $23.0(5.2)$ & Loam \\
\hline Shoulder & $3.4(0.04)$ & $3.5(1.9)$ & $11.5(7.8)$ & $8.2(2.3)$ & $25.2(13.0)$ & $52.0(4.7)$ & $22.9(8.3)$ & Silt loam \\
\hline Side Slope & $8.5(5.5)$ & $3.6(1.5)$ & $7.8(2.9)$ & $5.9(0.2)$ & $33.5(6.8)$ & $42.4(0.5)$ & $24.2(6.3)$ & Loam \\
\hline Ditch & $10.9(13.3)$ & $5.9(1.4)$ & $8.0(0.6)$ & $6.8(0.5)$ & $31.5(11.0)$ & $44.2(11.7)$ & $24.3(0.7)$ & Loam \\
\hline Backslope & $1.0(1.4)$ & $0.4(0.6)$ & $5.2(7.3)$ & $4.6(6.5)$ & $22.3(8.8)$ & $56.4(16.3)$ & $21.4(7.5)$ & Silt loam \\
\hline Field Edge & 0 & 0 & 0 & 0 & $25.4(12.7)$ & $51.6(4.2)$ & $23.0(8.5)$ & Silt loam \\
\hline \multicolumn{9}{|c|}{ Sargent } \\
\hline Road edge & $6.2(3.4)$ & $2.2(3.0)$ & $20.8(5.8)$ & $6.1(1.5)$ & $67.4(8.5)$ & $26.0(5.1)$ & $6.6(3.3)$ & Sandy loam \\
\hline Shoulder & $12.2(13.7)$ & $1.4(1.9)$ & $14.8(5.9)$ & $5.0(1.3)$ & $51.4(13.1)$ & $27.3(22.1)$ & $21.4(9.1)$ & Sandy clay loam \\
\hline Side Slope & $0.5(0.4)$ & $2.9(2.6)$ & $14.3(13.5)$ & $4.7(3.7)$ & $46.6(23.0)$ & $40.7(14.4)$ & $12.7(8.5)$ & Loam \\
\hline Ditch & $0.05(0.07)$ & $0.2(0.2)$ & $1.5(0.3)$ & $1.1(0.2)$ & $35.9(6.6)$ & $50.2(6.3)$ & $13.9(0.3)$ & Silt loam \\
\hline Backslope & 0 & 0 & $0.08(0.1)$ & $0.4(0.6)$ & $26.5(4.2)$ & $62.2(4.2)$ & $11.4(0.01)$ & Silt loam \\
\hline Field Edge & 0 & 0 & 0 & $1.1(1.5)$ & $42.6(25.5)$ & $47.0(23.6)$ & $10.4(1.9)$ & Loam \\
\hline \multicolumn{9}{|c|}{10 to $20 \mathrm{~cm}$} \\
\hline \multicolumn{9}{|c|}{ Beaver Crossing } \\
\hline Road edge & $4.5(1.8)$ & $1.9(0.03)$ & $4.3(0.6)$ & $5.8(2.4)$ & $24.8(7.1$ & $48.6(10.5)$ & $26.7(3.3)$ & Loam \\
\hline Shoulder & $4.5(6.4)$ & $3.6(5.1)$ & $4.5(6.4)$ & $4.8(6.7)$ & $23.4(1.6)$ & $51.1(6.2)$ & $25.5(4.6)$ & Loam \\
\hline Side Slope & $4.6(0.4)$ & $3.1(2.2)$ & $13.8(1.6)$ & $7.7(0.1)$ & $27.1(9.0)$ & $50.5(11.5)$ & $22.5(2.5)$ & Silt loam \\
\hline Ditch & $1.7(2.4)$ & $1.6(1.4)$ & $6.3(5.1)$ & $5.2(0.9)$ & $28.0(17.3)$ & $47.0(9.6)$ & $31.1(0.9)$ & Clay loam \\
\hline Backslope & 0 & 0 & 0 & 0 & $23.4(9.1)$ & $47.7(9.3)$ & $29.0(0.2)$ & Clay loam \\
\hline Field Edge & 0 & 0 & 0 & 0 & $19.0(7.8)$ & $52.4(8.1$ & $28.6(0.3)$ & Silty clay loam \\
\hline
\end{tabular}




\begin{tabular}{|c|c|c|c|c|c|c|c|c|}
\hline \multicolumn{9}{|c|}{ Sargent } \\
\hline Road edge & $21.3(9.6)$ & $3.4(4.7)$ & $20.1(2.3)$ & $5.6(0.2)$ & $67.1(10.6)$ & $23.8(7.2)$ & $9.1(3.4)$ & Sandy loam \\
\hline Shoulder & $8.1(1.3)$ & $0.3(0.3)$ & $7.8(4.6)$ & $3.0(0.5)$ & $51.9(15.3)$ & $32.2(12.6)$ & $12.8(1.6)$ & Loam \\
\hline Side Slope & $5.8(0.04)$ & $2.3(0.6)$ & $9.5(1.1)$ & $4.1(2.0)$ & $47.2(5.5)$ & $40.3(3.9)$ & $12.5(1.6)$ & Loam \\
\hline Ditch & $0.3(0.4)$ & 0 & $1.1(0.6)$ & $1.5(0.6)$ & $37.1(11.3)$ & $45.3(5.9)$ & $17.7(5.4)$ & Loam \\
\hline Backslope & 0 & 0 & $0.1(0.1)$ & $0.7(1.0)$ & $20.1(9.3)$ & $68.5(5.9)$ & $11.4(3.4)$ & Silt loam \\
\hline Field Edge & 0 & 0 & 0 & $0.1(0.1)$ & $48.4(30.2)$ & $37.6(30.5)$ & $13.9(0.2)$ & Loam \\
\hline
\end{tabular}

